\title{
Effect of eicosapentaenoic acid on bovine cumulus-oocyte complex in vitro
}

\author{
Noelia Nikoloff, Ana M. Pascua, Juan M. Anchordoquy, Juan P. Anchordoquy, Matías A. Sirini, \\ Analia Seoane and Cecilia C. Furnus*
}

IGEVET-Instituto de Genética Veterinaria "Ing. Fernando N Dulout" (UNLP-CONICET LA PLATA), Facultad de Ciencias Veterinarias UNLP, Calles 60 y 118, B1904AMA La Plata, Buenos Aires, Argentina

\begin{abstract}
The aim of the present study was to investigate the effects of eicosapentaenoic acid (EPA) supplementation during in vitro maturation (IVM) of bovine oocytes. The concentrations tested in all experiments were $1 \mathrm{nM}, 1 \mu \mathrm{M}$, and $1 \mathrm{mM}$ EPA. The effect of EPA was evaluated on cumulus-oocyte complexes (COC) by oocyte maturation (cumulus expansion area and oocyte nuclear maturation), genotoxicity [single cell gel electrophoresis (SCGE)], and cytotoxicity (apoptosis, viability, and MTT assays) end points. The maturation parameters were affected by exposure of COC to different EPA concentrations in the IVM medium. Cumulus expansion area increased in the presence of $1 \mathrm{nM} \mathrm{EPA}(P<0.05)$ whereas addition of $1 \mathrm{nM} \mathrm{EPA}(P<0.05)$ decreased cumulus expansion after $24 \mathrm{~h}$ of IVM. Moreover, the maturation rate significantly decreased when $1 \mathrm{mM}$ of EPA was assayed $(P<0.001)$. EPA at $1 \mathrm{nM}$ induced genotoxic and cytotoxic effects on bovine cumulus cells $(\mathrm{CC})$ and primary DNA lesions $(P<0.001)$. A significant increase in the frequency of apoptotic $(P<0.01)$ and necrotic $(P<0.001)$ cells was observed after $24 \mathrm{~h}$ of treatment with $1 \mathrm{nM}, 1 \mu \mathrm{M}$, and $1 \mathrm{mM}$ EPA. Mitochondrial activity was altered with $1 \mathrm{mM} \mathrm{EPA}(P<0.001)$. We inferred that optimal oocyte quality was partially dependent on the presence of adequate EPA concentrations; EPA could be beneficial to improve oocyte quality in the maturation process, because low concentration tested ( $1 \mathrm{nM} \mathrm{EPA})$ improved cumulus expansion.
\end{abstract}

Keywords: apoptosis; bovine; EPA; MTT; single cell gel electrophoresis

\section{Introduction}

Fatty acids are classified into saturated, monounsaturated, and polyunsaturated fatty acids (PUFA). Since mammals, including humans, are unable to synthesize $n-3$ and n-6 PUFAs, they are considered essential nutrients because they must be incorporated with the diet (Simopoulos, 1989).

Several reports indicate that PUFAs play an important role in male and female reproduction (Trujillo and Broughton, 1995; Wathes et al., 2007; Aardema et al., 2011; Liu et al., 2015; Veshkini et al., 2015). EPA is a n-3 fatty acid available in marine organisms. EPA has been shown to offer protection against coronary disease, thrombosis, ischemic brain injury, scalis dermatitis, and some inflammatory disease (Takeuchi et al., 1989; Yerram et al., 1989). However, little is known about their importance in oocyte and embryo physiology. Oocyte lipids are used as energy source and also contribute with energy requirements of fertilization, cell differentiation, and preimplantation embryos (Amri et al., 1994; Wathes et al., 2007). Furthermore, oocyte lipids may participate not only in fertilization but also in the subsequent cell differentiation. The content of PUFAs in oocytes can affect maturation, cryopreservation, and subsequent developmental competence. Kim et al. (2001) demonstrated that oocyte lipids are available to be used as energy source for maturation and that serum lipids added to in vitro maturation (IVM) medium are incorporated into the cytoplasm during IVM. Moreover, changes in the fatty acid composition of bovine oocytes

\footnotetext{
*Corresponding author: e-mail: cfurnus@fcv.unlp.edu.ar

Abbreviations: CC, cumulus cells; COC, cumulus-oocyte complex; D, degenerates; DMSO, dimethyl sulfoxide; EPA, eicosapentaenoic acid; ETOH, ethanol; FDA, fluorescein diacetate; FITC, fluorescein isothiocyanate; GDI, genetic damage index; GV, germinal vesicle; IVM, in vitro maturation; MI, metaphase I; MII+PB, metaphase II+polar body; MTT, 3(4,5-dimethylthiazol-2-yl)-2,5-diphenyltetrazolium bromide; PI, propidium iodide; PUFA, polyunsaturated fatty acid; ROS, reactive oxygen species; SCGE, single cell gel electrophoresis
} 
improved oocyte maturation and cryopreservation (Kim et al., 2001). Indeed, PUFAs act as mediators in a series of processes, such as cell membrane fluidity, intracellular signaling, and susceptibility to oxidative damage in several reproductive tissues (Wathes et al., 2007).

Bovine oocyte IVM medium supplemented with PUFAs altered oocyte meiosis and subsequent early embryo development (Marei et al., 2010). Knowledge of the fatty acids having beneficial effects for oocyte and embryo development may allow the feeding of diets rich in certain fatty acid(s) to enhance fertility. Further, the supply of lipids as substrates during IVM could impact in the earliest stages of embryo development.

Successful reproduction depends on the capacity of an ovulated oocyte to undergo fertilization and on the subsequent embryo and fetal development. It also requires the coordinated and stepwise growth of the oocyte and its companion somatic cells into the ovarian follicle (Dunning et al., 2014). Evidence in the literature indicates that lipid metabolism in the bovine cumulus-oocyte complex (COC) influences subsequent oocyte developmental potential. Oocytes and CC contain lipid droplets, but their role during oocyte maturation is not fully understood (Dunning et al., 2014).

Genotoxicity and cytotoxicity studies have been conducted to test numerous compounds using several end points on different test systems (Anchordoquy et al., 2014; Nikoloff et al., 2016; Ruiz de Arcaute et al., 2016). Numerous works have shown that the use of CC and oocyte in vitro for genotoxic and cytotoxic evaluation is a valuable and good tool for the rapid and sensitive detection of effect induced by various compound (Anguita et al., 2007; Chung et al., 2007). Furthermore, single cell gel electrophoresis (SCGE), apoptosis, and MTT assay are test used to indicate COC quality (Li et al., 2009; Osman et al., 2013; Aziz et al., 2014). Since few studies have reported the effects of eicosapentaenoic acid (EPA; an n-3 PUFA from fish oil) on bovine oocyte and CC, the aim of this study was to evaluate the influence of EPA supplementation during bovine IVM on CC expansion and oocyte nuclear maturation. Furthermore, we evaluated biomarkers such as SCGE, and apoptosis and viability assays in COC to characterize the genotoxicity and cytotoxicity exerted by EPA.

\section{Materials and methods}

\section{Reagents and media}

All reagents for media preparation were purchased from Sigma Chemical Co. (St. Louis, MO, USA). FSH was purchased from Bioniche (Belleville, Ontario, Canada). Bicarbonate-buffered TCM-199 with Earle's salts supplemented with $10 \%$ fetal calf serum (FCS) was used as maturation medium in all experiments. EPA (CAS 1041794-4) was obtained from Cayman Chemical (Ellsworth, USA). Annexin V-FITC was purchased from Biosourse International, Inc. (USA). 3(4,5-dimethylthiazol-2-yl)-2,5-diphenyltetrazolium bromide (MTT) (CAS 57360-69-7) and propidium iodide (PI) (CAS 25535-16-4) were purchased from Sigma Chemical Co. Ethanol (ETOH) was purchased from Merck KGaA (Darmstadt, Germany). Bleomycin (Blocamycin ${ }^{\circledR}$ ) was kindly provided by Gador S.A. (Buenos Aires, Argentina).

\section{Oocytes and experimental design}

Bovine ovaries were obtained from an abattoir and transported to the laboratory in sterile $\mathrm{NaCl}$ solution $(9 \mathrm{~g} / \mathrm{L})$ with antibiotics at $37^{\circ} \mathrm{C}$ within $3 \mathrm{~h}$ of slaughter. The ovaries were pooled regardless of the estrous cycle stage of donors. COC were aspirated from follicles (3-8 $\mathrm{mm}$ ) using an $18-\mathrm{G}$ needle. We only selected cumulus-intact oocytes with an evenly granulated cytoplasm using a low-power (20-30×) stereomicroscope.

The methodological design for all tests was as follows: COC were treated with three different EPA concentrations ( $1 \mathrm{nM}, 1 \mu \mathrm{M}$, and $1 \mathrm{mM})$. Dose selection was based on previous studies (Bartl et al., 2014; Dendelé et al., 2014). Prior to use, EPA was dissolved in ETOH and stored as stock solution at $-20^{\circ} \mathrm{C}$. EPA concentrations were prepared freshly from the stock solution and then diluted with the appropriate volumes of the adequate culture medium (TCM 199). COC were matured for $24 \mathrm{~h}$ as described above. Thereafter, nuclear maturation and the genotoxic and cytotoxic effect of EPA were evaluated using 80 COC per treatment for IVM. Replicates of experiments (3-5) were performed on different days, with separate COC batches each day. Negative (untreated CC and solvent vehicle cells) and positive controls were run simultaneously with EPAtreated COC. A negative control (untreated cells), a solvent control (cells treated with the concentration of ETOH to dilute the EPA) were used in all genotoxicity and cytotoxicity assays to verify that the solvent does not damage the system. Positive control (we used 5\% ETOH for MTT and apoptosis and $1 \mu \mathrm{g} / \mathrm{mL}$ BLM for SCGE and viability) to validate the effectiveness of the tests in our system. The same batches of culture medium, serum, and reagents were used throughout the study.

\section{In vitro maturation}

Oocyes were washed twice in TCM-199 buffered with $15 \mathrm{mM}$ Hepes and containing 10\% (v/v) FCS and twice in IVM medium. Groups of 10 COC were transferred into $50 \mu \mathrm{L}$ of IVM medium under mineral oil (Squibb, USA) preequilibrated in a $\mathrm{CO}_{2}$ incubator. $\mathrm{COC}$ were cultured in 
IVM medium for $24 \mathrm{~h}$ at $39^{\circ} \mathrm{C}$ in $5 \% \mathrm{CO}_{2}$ in air with saturated humidity.

\section{Analysis of cumulus expansion area}

Cumulus expansion was measured in each COC after IVM using a computerized image-digitizing system with Image ProPlus ${ }^{\circledR} 3.1$ to measure irregular areas. System units were transformed to $\mu \mathrm{m}^{2}$ by calibration with a Maklert chamber. For comparison, each COC area was measured before IVM. Results were expressed as the mean of averaging all COC expansion values within each experimental group.

\section{Analysis of oocyte nuclear maturation}

After IVM, oocytes were placed in TCM-199 medium $+0.2 \%$ hyaluronidase at room temperature, and then pipetted to remove CC. Oocyte nuclear maturation was assessed by mounting and staining the denuded oocytes with Hoechst 33342, a fluorescent DNA-specific dye. Oocytes were then examined under an epifluorescence microscope Olympus BX40 (Olympus, Tokyo, Japan) equipped with an appropriate filter combination, and classified as germinal vesicle (GV), metaphase I (MI), or metaphase II+polar body $(\mathrm{MII}+\mathrm{PB})$ stage of maturation process (Izadyar et al., 1997; Suss et al., 1998). Oocytes with abnormal or no chromatin configuration were classified as degenerates (D). Results were expressed as oocyte percentages with different status of nuclear maturation.

\section{SCGE assay for DNA damage analysis}

SCGE is a simple, sensitive, and fast procedure to detect primary DNA damages in any eukaryotic cell type (Møller, 2006). After IVM, 10 oocytes from each treatment were stripped of surrounding CC by repeated pipetting with a narrow-bore glass pipette in TCM-199 buffered with HEPES. CC were washed three times in PBS containing $5 \%$ FCS. Complete cell disruption was achieved by repeated aspiration using a narrow-bore pipette. Normal-melting agarose $0.5 \%(180 \mu \mathrm{L})$ was transferred onto $100 \% \mathrm{ETOH}$ precleaned slides and placed at $37^{\circ} \mathrm{C}$ for $20-30 \mathrm{~min}$. Afterwards, $30 \mu \mathrm{L}$ of $\mathrm{CC}$ samples were resuspended in $150 \mu \mathrm{L}$ of $0.5 \%$ low-melting agarose, covered with a coverslip, and placed at $4^{\circ} \mathrm{C}$ for $10 \mathrm{~min}$. SCGE was performed according to the alkaline procedure described by Singh et al. (1988) with slight modifications. The slides were immersed overnight at $4^{\circ} \mathrm{C}$ in fresh lysis solution in darkness [ $1 \%$ sodium sarcosinate, $2.5 \mathrm{~m} \mathrm{NaCl}, 100 \mathrm{~mm}$ $\mathrm{Na}_{2}$ EDTA, $10 \mathrm{~mm}$ Tris, $\mathrm{pH} 10.0$, 1\% Triton $\mathrm{X}-100$, and $10 \%$ dimethyl sulfoxide (DMSO)]. Then, slides were placed in electrophoresis buffer ( $1 \mathrm{~mm} \mathrm{Na} \mathrm{EDT}_{2}$ T, $300 \mathrm{~mm} \mathrm{NaOH}$ ) for
$20 \mathrm{~min}$ at $4^{\circ} \mathrm{C}$ for cellular DNA unwinding, followed by electrophoresis in the same buffer and temperature for $20 \mathrm{~min}$ at $25 \mathrm{~V}$ and $250 \mathrm{~mA}(0.8 \mathrm{~V} / \mathrm{cm})$. Finally, the slides were neutralized with a $0.4 \mathrm{~m}$ Tris- $\mathrm{HCl}$ solution, $\mathrm{pH} 7.5$. Slides were stained with 1/1000SYBR Green I solution (Molecular Probes; Eugene, OR, USA) (Olive, 1999). Scoring was performed at $400 \times$ magnification using an Olympus BX40 fluorescence microscope equipped with a 515-560 nm excitation filter. The extent of DNA damage was quantified by the length of DNA migration, which was visually determined in 200 randomly selected and non overlapping cells per replicate. DNA damage was classified into four classes (0-I, undamaged; II, minimum damage; III, medium damage; IV, maximum damage), as previously reported by Cavaş and Könen (2007). Results are expressed as the mean number of damaged nucleoids (sum of classes II, III, and IV) and the mean comet score for each treatment group. Additionally, genetic damage index (GDI) for each test compound was determined with the formula GDI $=[(\mathrm{I})+2$ $(\mathrm{II})+3(\mathrm{III})+4(\mathrm{IV})] / \mathrm{N}(0-\mathrm{IV})$, where $0-\mathrm{IV}$ represents the nucleoid type, and N0-NIV represents the total number of nucleoids scored (Pitarque et al., 1999).

\section{FDA/Trypan blue assay for the viability analysis}

Viability was analyzed with the fluorescein diacetate (FDA)/ trypan blue assay (Hoppe and Bavister, 1984). CC suspensions from each treatment were incubated for $10 \mathrm{~min}$ at $37^{\circ} \mathrm{C}$ in PBS with $2.5 \mu \mathrm{g} / \mathrm{L}$ FDA and $2.5 \mathrm{~g} / \mathrm{L}$ trypan blue. Then, CC were washed in PBS and observed in a Nikon Optiphot epifluorescence microscope with a 409 fluor objective (Nikon, Tokyo, Japan) equipped with a 330$490 \mathrm{~nm}$ excitation filter and a 420-520 nm emission filter at $200 \times$ magnification. Live cells are visible in green fluorescence, whereas dead cells show a characteristic blue staining under white light. At least 500 cells were counted per experimental point, and results were expressed as the percentage of viable cells among all cells.

\section{Annexin V affinity assay for apoptosis analysis}

The assay was based on annexin $\mathrm{V}$ fluorescein isothiocyanate (FITC) binding ability to expose phosphatidylserine, an early indicator of apoptosis (van Engeland et al., 1998). Ten oocytes from each treatment were denuded and CC suspensions were washed in PBS, resuspended in $250 \mu \mathrm{L}$ of $1 \times$ binding buffer $(10 \mathrm{~mm}$ Hepes, $140 \mathrm{~mm} \mathrm{NaCl}$, and $2.5 \mathrm{~mm} \mathrm{CaCl}_{2}$ ), and exposed to annexin $2 \mu \mathrm{L} \mathrm{V}$-FITC for $15 \mathrm{~min}$ at room temperature in the dark. Afterwards, cells were washed with binding buffer and $2 \mu \mathrm{L}$ PI (stock solution, $10 \mu \mathrm{g} / \mathrm{mL}$ ) was added to each sample. Samples were analyzed under an epifluorescent microscope Olympus BX40 equipped with an appropriate filter combination. CC 
were classified following the criteria reported by Pläsier et al. (1999) as alive (annexin V negative/PI negative), earlyapoptotic (annexin $\mathrm{V}$ positive/PI negative), late-apoptotic (annexin $\mathrm{V}$ positive/PI positive), and necrotic cells (annexin $\mathrm{V}$ negative/PI positive). Each experiment was repeated three times and samples were performed in duplicate for each experimental point. The percentage of stained CC was determined by counting 100 cells per coverslip in at least four different fields (Lourenço et al., 2014). Results were expressed as the mean percentage of alive, early-apoptotic, late-apoptotic, and necrotic cells.

\section{MTT assay for mitochondrial activity analysis}

The MTT assay is used to determine the respiratory activity of the mitochondrial succinate-tetrazolium reductase system, which converts the yellow tetrazolium salt into a blue formazan dye (Robb et al., 1990). The MTT assay was performed following the protocol of Wu et al. (2013). Briefly, $1 \times 10^{4} \mathrm{CC} /$ well were cultured in TCM-199 on 96-well microplates for 4 days until the cells were nearly confluent. The culture medium was removed, and cells were treated with $1 \mathrm{nM}, 1 \mu \mathrm{M}$, and $1 \mathrm{mM}$ EPA dissolved in $100 \mu \mathrm{L}$ TCM199 for $24 \mathrm{~h}$. ETOH was used as positive and vehicle control. Then, MTT was added to each well at a final concentration of $0.25 \mathrm{mg} / \mathrm{mL}$, and incubated at $37^{\circ} \mathrm{C}$ for $3 \mathrm{~h}$. Afterwards $100 \mu \mathrm{L}$ DMSO were added to dissolve the formazan blue crystals. Measurement of absorbance was performed at $490 \mathrm{~nm}$ with a microplate spectrophotometer (Biotek Instruments, Inc., Bedfordshire, United Kingdom). Data were normalized to control culture measurements that were considered $100 \%$ cell survival. Results were expressed as mean percentage of mitochondrial activity from three independent experiments.

\section{Statistical analyses}

Cumulus expansion area was analyzed with linear models using SAS PROC MIXED (SAS Institute, Cary, NC, USA). Cumulus area before IVM (T0) was used as covariate to analyze cumulus expansion after $24 \mathrm{~h}$ of IVM.

SCGE data were compared by applying one-way ANOVA using Statgraphics 5.1 Plus software. Variables were tested for normality with the Kolmogorov-Smirnov test, and homogeneity of variances between groups was verified by the Levene test. Pairwise comparisons between different groups were analyzed with the post hoc least significant difference test. Differences in GDI, viability, oocyte nuclear maturation, and apoptosis between treated and control groups were evaluated by $\chi^{2}$ test. The two-tailed Student's $t$ test was used to compare MTT data. The level of significance was $P \leq 0.05$ unless indicated otherwise.

\section{Results}

\section{Analysis of cumulus expansion area}

Results of cumulus expansion area from COC exposed to different EPA concentrations during 24-h IVM are presented in Figure 1A. Figure 1A shows immature COC T0 (mean \pm S.E. of COC used for the experiment) and mature COC T24 (control and treatments with EPA after $24 \mathrm{~h}$ ). No significant differences were observed in COC T0 expansion area $(P>0.05)$. Cumulus expansion was not altered when COC were matured with $1 \mu \mathrm{M}$ EPA, as compared with the negative control after 24-h IVM $(P>0.05)$. However, cumulus expansion increased when COC were matured with $1 \mathrm{nM}$ EPA for $24 \mathrm{~h}$ as compared with control values $(P<0.001)$, whereas it decreased after addition of $1 \mathrm{mM}$ EPA to the IVM medium $(P<0.001)$. We did not observe statistical differences before (T0) and after (T24h) IVM in COC treated with $1 \mathrm{mM} \mathrm{EPA,} \mathrm{thus}$ suggesting that $1 \mathrm{mM}$ EPA suppresses cumulus expansion during IVM. Overall, this assay demonstrated that cumulus expansion was enhanced by $1 \mathrm{nM}$ EPA as compared with the other tested EPA concentrations. The use of $0.1 \% \mathrm{ETOH}$ as a solvent control did not show detrimental effects on CC expansion $(P>0.05)$ (Figure 1A).

\section{Analysis of oocyte nuclear maturation}

Oocytes matured with $1 \mathrm{nM}$ and $1 \mu \mathrm{M}$ EPA resulted in $58.23 \%$ and $60.00 \%$ nuclear maturation rate, respectively, which were not significantly different with respect to the control group (65.98\%). Maturation rate significantly decreased when $1 \mathrm{mM}$ EPA was assayed $(P<0.001)$. One millimolar EPA increased the frequency of GV, MI, and D $(P<0.001)$, whereas it caused the reduction in the rate of oocytes in $\mathrm{MII}+\mathrm{PB}$ with respect to control values $(P<0.001$; Figure 1B).

The regression analysis demonstrated that the maturation rate directly correlated with EPA concentration $(\mathrm{R}=0.98$; $P<0.05)$. The use of $0.1 \% \mathrm{ETOH}$ as a solvent control did not show detrimental effects on nuclear maturation status $(P>0.05)$ (Figure 1B).

\section{SCGE assay for DNA damage analysis}

Figure 2A present the data of the SCGE assay from CC exposed during $24 \mathrm{~h}$ to different EPA concentrations. ETOH treatment (solvent control) did not alter the frequency of damaged nucleoids compared with the negative control $(P>0.05)$. Bleomycin $(1 \mu \mathrm{g} / \mathrm{mL}$; positive control $)$ induced an increase in the frequency of damaged cells when compared to the negative control $(P<0.001)$. The frequency of damaged CC was higher in the presence of $1 \mathrm{nM} E P A$ than 

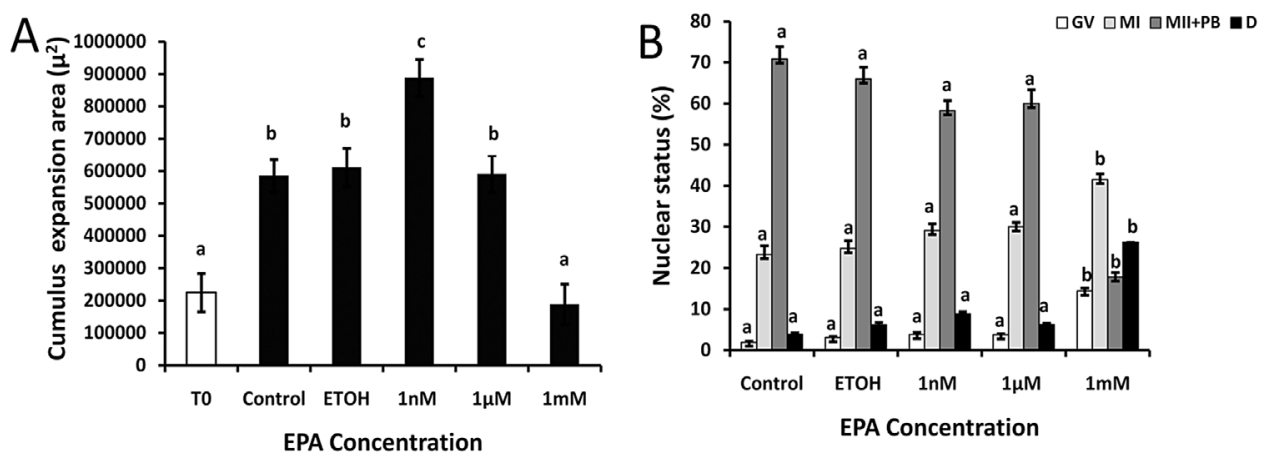

Figure 1 Effect of eicosapentaenoic acid (EPA) in in vitro maturation of bovine COC. Bovine COC were matured in vitro in medium with (a) IVM (Control); (b) $0.1 \%$ ETOH (ethanol, solvent control);(c) $1 \mathrm{nM} \mathrm{EPA;} \mathrm{(d)} 1 \mu \mathrm{M} \mathrm{EPA;} \mathrm{and} \mathrm{(e)} 1 \mathrm{mM}$ EPA during $24 \mathrm{~h}$ of IVM. (A) Cumulus expansion area measured in COC treated with EPA during IVM. Data are expressed as means \pm SEM. White bar: TO (means \pm SEM to immature COC used in all experiments); Black bars: T24 (COC matured for 24 h); (B) Effect of EPA on nuclear status of bovine COC matured in vitro. After IVM, oocyte nuclear maturation was assessed with Hoechst 33342 and classified in GV (germinal vesicle), MI (metaphase I), and MII + PB (metaphase II+polar body) stage of maturation process. Oocytes with abnormal chromatin configuration were classified as $D$ (degenerate). All values for bovine oocytes are expressed as mean \pm SEM. (A) ${ }^{a-c}$ Bars with different letters differ $(P<0.05)$. (B) ${ }^{a-b}$ Bars with different letters in the same category differ $(P<0.05)$.

in the negative controls $(P<0.001)$. However, the frequency of DNA damage was not significantly increased when CC were exposed to $1 \mu \mathrm{M}$ and $1 \mathrm{mM}$ EPA $(P>0.05$; Figure $2 \mathrm{~A})$. The GDI values were (negative control: 0.18 ; solvent control:
0.21; $1 \mathrm{nM}$ EPA: $0.43 ; 1 \mu \mathrm{M}$ EPA: $0.16 ; 1 \mathrm{mM}$ EPA: 0.16 ; positive control: 0.92 ). Increase of GDI was observed in COC maturated in presence of positive control and $1 \mathrm{nM}$ EPA $(P<0.001)$.
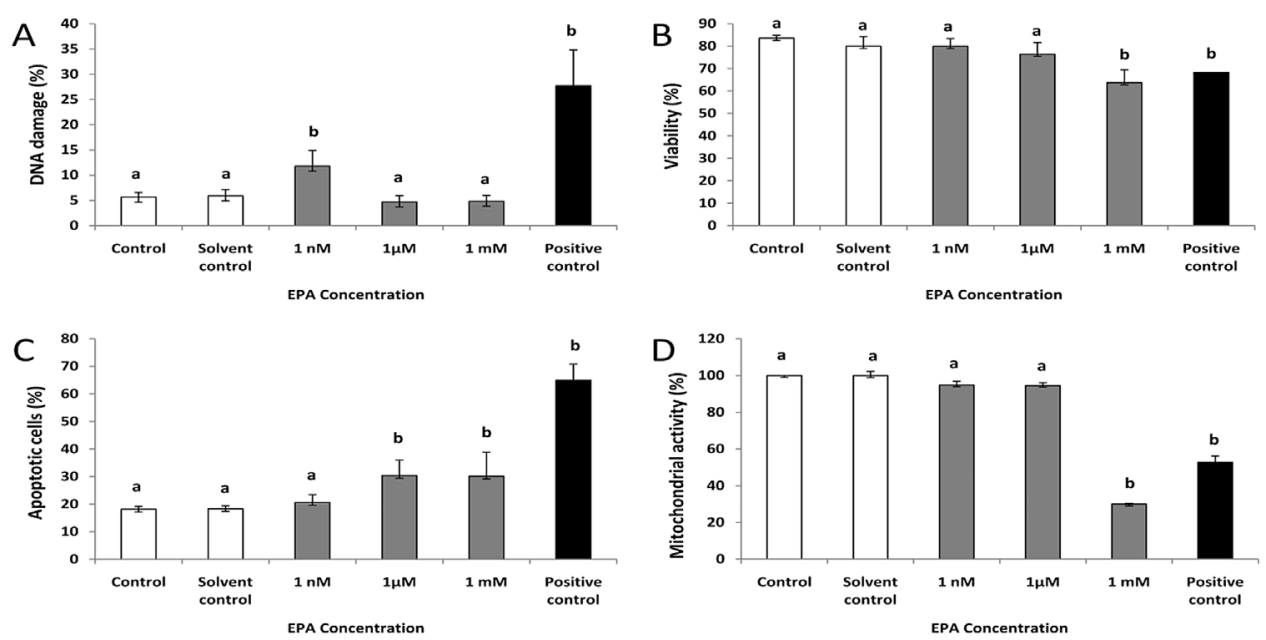

Figure 2 Effect of eicosapentaenoic acid (EPA) in in vitro maturation of bovine COC. Bovine COC were matured in vitro in medium with (a) IVM medium alone (Control); (b) $0.1 \%$ ethanol as a solvent control; (c) $1 \mathrm{nM}$ EPA; (d) $1 \mu \mathrm{M} \mathrm{EPA;} \mathrm{(e)} 1 \mathrm{mM}$ EPA during $24 \mathrm{~h}$ of IVM. (A) DNA damaged in CC were evaluated by SCGE in four replicates. The extent of DNA damage was quantified by the length of DNA migration (Comet), which was visually determined in 200 randomly selected and non-overlapping cells per replicate. DNA damage was classified into four classes: 0-I (undamaged); II (minimum damage); III (medium damage); and V (maximum damage). Results are expressed as mean of DNA damage (sum of classes II, III, and IV). Bleomycin $(1 \mu \mathrm{g} / \mathrm{mL}$ ) as used as a Positive control of SCGE assay; (B) viability was analyzed with the fluorescein diacetate/trypan blue assay. Live CC are visible in green fluorescence and dead CC in blue. At least 500 cells were counted per experimental point. Results are presented as mean \pm SEM. Bleomycin $(1 \mu \mathrm{g} / \mathrm{mL}$ ) as used as a positive control of viability assay; (C) apoptosis was evaluated by Annexin V-FITC-Propidium iodide (PI). CC were classified as Alive (annexin $\vee$ negative/PI negative); early-apoptotic (annexin $\vee$ positive/PI negative); late-apoptotic (annexin $\vee$ positive/PI positive); and necrotic cells (annexin $\vee$ negative/PI positive). Results are expressed as percentage as mean of apoptotic cells \pm SEM: early apoptotic+late apoptotic. Each experiment was repeated three times and samples were performed in duplicate for each experimental point. The percentage of stained CC was determined by counting 100 cells per coverslip in at least four different fields. Ethanol (5\%) was used as a positive control of apoptosis; (D) mitochondrial activity was evaluated by MTT assay. Results are expressed as means \pm SEM of mitochondrial activity from three independent experiments. Ethanol (5\%) as used as a positive control of MTT assay. ${ }^{a-c}$ Bars with different letters differ $(P<0.05)$. 
FDA/Trypan blue assay for the viability analysis

Concerning CC viability assay, no significant alterations were found in CC treated with $1 \mathrm{nM}$ and $1 \mu \mathrm{M}$ EPA compared to controls $(P>0.05)$. On the other hand, cell viability decreased in CC treated with $1 \mathrm{mM}$ EPA $(P<0.05)$ (Figure 2B).

\section{Annexin V affinity assay for apoptosis analysis}

Data of apoptosis detection by annexin $\mathrm{V}$ affinity assay of CC after $24 \mathrm{~h}$ of exposure to EPA are presented in Figure 2C. ETOH treatment (solvent control) did not alter the frequency of apoptotic cells compared with the negative control $(P>0.05)$. The positive control modified the frequency of apoptotic cells $(P<0.001)$. Results revealed an enhancement of apoptotic cells when COC were treated with $1 \mu \mathrm{M}$ and $1 \mathrm{mM}$ EPA $(P<0.01)$ due to an increased frequency of late apoptotic cells (data not shown) $(P<0.001)$. Also $1 \mathrm{mM}$ EPA modified the frequency of living cells $(P<0.001)$ compared to control values (data not shown). Induction of apoptosis was not observed in COC treated with the lowest EPA concentration tested, although we observed that $1 \mathrm{nM}$ EPA induced a significant alteration in the frequency of late apoptotic cells $(P>0.001)$ (data not shown). In addition, an increase in the frequency of necrotic cells was observed $(P<0.001)$ regardless of the EPA concentration tested (negative control: 3.33\%; solvent control: $1.67 \%$; $1 \mathrm{nM}$ EPA: 9.87\%; $1 \mu \mathrm{M}$ EPA: $6.76 \%$; $1 \mathrm{mM}$ EPA: $19.66 \%$; positive control: $18.00 \%$ ).

\section{MTT assay for mitochondrial activity analysis}

The alterations in cell energetic metabolism induced by EPA are summarized in Figure 2D. The positive control produced a significant toxicity in CC cells as compared with the negative controls $(P<0.001)$. ETOH treatment (solvent control) did not modify CC viability with respect to control values. Cellular metabolism was inhibited when CC were exposed to $1 \mathrm{mM}$ EPA $(P<0.001)$. Conversely, no statistical alteration in mitochondrial activity was observed when CC were exposed to $1 \mathrm{nM}$ and $1 \mu \mathrm{M}$ EPA $(P>0.05)$.

\section{Discussion}

Recent studies strongly suggest that lipids have metabolic functions during oocyte maturation, fertilization, and early embryonic development (Adamiak et al., 2006; Wathes et al., 2007; Aardema et al., 2011; Lapa et al., 2011). Indeed, the maturation process fully depends on the ability of oocytes to acquire the potential to develop until the blastocyst stage (Sturmey et al., 2009; Dunning et al., 2014). In the present study, we evaluated the effect of EPA, PUFA derived from fish oil, during bovine oocyte IVM by analyzing cumulus expansion and nuclear maturation status. Additionally, SCGE, viability, apoptosis, and MTT assay were further evaluated to determine whether treatment with EPA could induce genotoxicity and cytotoxicity effects on bovine COC.

Our results demonstrated that all the maturation parameters evaluated in this study were affected by exposure to different EPA concentrations. Cumulus expansion area increased in the presence of $1 \mathrm{nM}$ EPA, whereas addition of $1 \mathrm{mM}$ EPA decreased cumulus expansion after 24-h IVM. Moreover, the maturation rate significantly decreased when $1 \mathrm{mM}$ EPA was assayed. Available data about the effect of EPA on bovine COC in vitro is scarce. So far, only Marquez et al. (2007) have reported the effect of EPA on bovine oocyte during IVM. These authors observed that 10 and $100 \mu \mathrm{M}$ EPA supplementation did not influence oocyte nuclear maturation. Our results were similar to the findings of Marquez et al. (2007) when we evaluated $1 \mu \mathrm{M}$ EPA. However, addition of $1 \mathrm{nM}$ EPA during IVM of bovine COC was beneficial since it increased the cumulus expansion area. In contrast, $1 \mathrm{mM}$ EPA decreased cumulus expansion area and altered maturation rates. CC expansion is an important marker for oocyte maturation; inhibition of CC expansion was shown to be independent of nuclear maturation but essential for fertilization and embryo development in cattle (Chen et al., 1990; Gutnisky et al., 2007; Wrenzycki and Stinshoff, 2013). The hyaluronic acid production by CC is essential for CC expansion, but it also plays a crucial role for oocyte maturation and further blastocyst development (Marei et al., 2012).

Another purpose of this work was to investigate the in vitro genotoxicity effect exerted by EPA on bovine COC. We used the comet assay to analyze DNA damage in CC incubated with EPA. The assay is simple, sensitive, and represents a fast procedure to detect genotoxicity in any eukaryotic cell type after xenobiotic exposure. It is usually used to both identify and quantify short-lived DNA damage (Brendler-Schwaab et al., 2005; Møller, 2006). We demonstrated that EPA only induced primary DNA lesions at $1 \mathrm{nM}$, but not at $1 \mu \mathrm{M}$ and $1 \mathrm{mM}$ EPA concentrations after $24 \mathrm{~h}$ of treatment. This observation might indicate that decreased DNA damage, as shown by a reduction in the comet tail, could be related to several aspects of cell cytotoxicity. We should take into account that cell damage evaluation of CC incubated with $1 \mu \mathrm{M}$ and $1 \mathrm{mM}$ EPA could be limited by dead cells, leaving only a reduced proportion of cells to be included in the comet score.

In the present study, apoptosis was detected by the Annexin V-FITC assay. Our current observations reveal that EPA induced a significant increase in the frequency of apoptotic and necrotic cells after $24 \mathrm{~h}$ of treatment consistent with SCGE data. However, $1 \mu \mathrm{M}$ and $1 \mathrm{mM}$ EPA induced a strong increase in the level of early and late apoptosis, 
whereas $1 \mathrm{nM}$ increased only the frequency of late apoptotic cells. The close contact between CC and oocyte through gap junctions allows the bidirectional interchange of molecules (Sofie, 2002). Consequently, the apoptotic process in CC alters oocyte quality, and subsequent embryo development in vitro may be affected. These somatic cells play an important role in regulating nucleus and cytoplasm oocyte maturation (Sofie, 2002), as well as in protecting oocytes against oxidative stress (Tatemoto et al., 2000). Our findings are in agreement with the genotoxic profile shown in other cellular systems. In human cell lines A375, A2058, and G361 exposed to $100 \mathrm{mM}$ EPA, the fatty acid decreased cellular proliferation (Zajdel et al., 2013). These results are consistent with those reported by Meng et al. (2013) showing that EPA at $25,50,75,100,125,150$, and $175 \mu \mathrm{M}$ resulted in a significant decrease of cell viability in RWPE- 1 and PC-3 cells when compared with the control group. In contrast, Bartl et al. (2014) confirmed that PUFAs enhanced cell viability in PC12 cells in a concentration range of $10 \mathrm{pM}$ to $1 \mu \mathrm{M}$.

The MTT assay is routinely employed in cytotocity studies to detect the metabolic reduction of MTT by the enzyme mitochondrial succinate dehydrogenase in formazan. CC incubated with $1 \mathrm{mM}$ EPA resulted in a reduction of mitochondrial activity; however, no alteration in cell viability was observed with $1 \mathrm{mM}$ and $1 \mu \mathrm{M}$ EPA. In previous studies, Sarabi et al. (2014) demonstrated that $100 \mu \mathrm{M}$ EPA did not induce cell death using the MTT assay in human THP-1 cells. Additional studies are needed to investigate the mechanism by which $1 \mathrm{mM}$ EPA affects mitochondrial activity.

To our knowledge, we have conducted the first genotoxic and cytotoxic evaluation of the fatty acid EPA in bovine oocyte and CC during IVM. As stated previously, our results revealed that EPA induced genotoxicity and cytotoxicity in bovine COC. The ability of PUFAs to induce genotoxicity and cytotoxicity could be attributed to the increased susceptibility to lipid peroxidation. PUFAs are an easy target to be damaged by free radicals and generate lipid peroxides that are very toxic to cell health. The formation of ROS after peroxidation of long chain PUFAs has been proposed as the primary mechanism of DNA and proteins damage. Also, aldehyde lipid peroxidation products cause mutations and genomic instability, leading to uncontrolled proliferation or cell death (Das, 2011; Santos and Schulze, 2012). Previous works suggest that the effect of fatty acids on in vitro systems partially depends on the concentration, the fatty acid and the cell type used in the study (Meng et al., 2013; Zajdel et al., 2013). Our results are in agreement with this suggestion because CC were more affected with the highest EPA concentration in all the tests performed in this work. Furthermore, our studies highlight the importance of employing multiple assays for characterizer the effect of EPA on bovine $\mathrm{COC}$ in vitro.

\section{Conclusions}

In conclusion, the present results indicate that EPA induced a genotoxic and cytotoxic effect and that such effect depended on the concentration tested, at least in our study model. However, EPA may be beneficial to improve oocyte quality in the maturation process, because low concentration tested in our study could improve the cumulus expansion. Further studies are needed to understand whether oocyte or CC lipid content may indeed be a biomarker of competence and, more importantly, whether lipid content physiological or in vitro alterations in COC may impact on subsequent embryo development.

\section{Acknowledgments and funding}

We are grateful to the staff of Frigorífico Gorina S.A. for providing the bovine ovaries. We also thank A. Di Maggio for manuscript correction. This work was supported by grants from Agencia Nacional de Promoción Científica y Tecnológica de la República Argentina (PICT BID 1972-2013), Ministerio de Ciencia, Tecnología e Innovación Productiva de la Nación Argentina.

\section{Conflict of interest}

The authors declare that there are no conflicts of interest.

\section{References}

Aardema H, Vos PLAM, Lolicato F, Roelen BAJ, Knijn HM, Vaandrager AB (2011) Oleic acid prevents detrimental effects of saturated fatty acids on bovine oocyte developmental competence. Biol Reprod 85: 62-9.

Adamiak SJ, Powell K, Rooke JA, Webb R, Sinclair KD (2006) Body composition, dietary carbohydrates and fatty acids determine post-fertilisation development of bovine oocytes in vitro. Reproduction 131: 247-58.

Amri EZ, Ailhaud G, Grimaldi PA (1994) Fatty acids as signal transducing molecules: involvement in the differentiation of preadipose to adipose cells. J Lipid Res 35: 930-7.

Anchordoquy JP, Anchordoquy JM, Picco SJ, Sirini MA, Errecalde AL, Furnus CC (2014) Influence of manganese on apoptosis and glutathione content of cumulus cells during in vitro maturation in bovine oocytes. Cell Biol Int 38: 246-53.

Anguita B, Vandaele L, Mateusen B, Maes D, Van Soom A (2007) Developmental competence of bovine oocytes is not related to apoptosis incidence in oocytes, cumulus cells and blastocysts. Theriogenology 67: 537-49.

Aziz NAA, Osman NA, Bidin H, Embong WK, Hashim NH (2014) Influence of early apoptosis incidence on in vitro maturation of bovine oocytes. APCBEE Procedia 8: 272-6.

Bartl J, Walitza S, Grünblatt E (2014) Enhancement of cell viability after treatment with polyunsaturated fatty acids. Neurosci Lett 559: 56-60. 
Brendler-Schwaab S, Hartmann A, Pfuhler S, Speit G (2005) The in vivo comet assay: use and status in genotoxicity testing. Mutagenesis 20: 245-54.

Cavaş T, Könen S (2007) Detection of cytogenetic and DNA damage in peripheral erythrocytes of goldfish (Carassius auratus) exposed to a glyphosate formulation using the micronucleus test and the comet assay. Mutagenesis 22: 263-8.

Chen L, Wert SE, Hendrix EM, Russell PT, Cannon M, Larsen WJ (1990) Hyaluronic acid synthesis and gap junction endocytosis are necessary for normal expansion of the cumulus mass. Mol Reprod Dev 26: 236-47.

Chung J, Tosca L, Huang T, Xu L, Niwa K, Chian R (2007) Effect of polyvinylpyrrolidone on bovine oocyte maturation in vitro and subsequent fertilization and embryonic development. Reprod Biomed Online 15: 198-207.

Das UN (2011) Essential fatty acids enhance free radical generation and lipid peroxidation to induce apoptosis of tumor cells. Clinical Lipidology 6: 463-89.

Dendelé B, Tekpli X, Hardonnière K, Holme JA, Debure L, Catheline D (2014) Protective action of n-3 fatty acids on benzo[a]pyrene-induced apoptosis through the plasma membrane remodeling-dependent NHE1 pathway. Chem Biol Interact 207: 41-51.

Dunning KR, Russell DL, Robker RL (2014) Lipids and oocyte developmental competence: the role of fatty acids and oxidation. Reproduction 148: R15-27.

Gutnisky C, Dalvit GC, Pintos LN, Thompson JG, Beconi MT, Cetica PD (2007) Influence of hyaluronic acid synthesis and cumulus mucification on bovine oocyte in vitro maturation, fertilisation and embryo development. Reprod Fertil Dev 19: 488-97.

Hoppe R, Bavister B (1984) Evaluation of the fluorescein diacetate (FDA) vital dye viability test with hamster and bovine embryos. Anim Reprod Sci 6: 323-5.

Izadyar F, Colenbrander B, Bevers MM (1997) Stimulatory effect of growth hormone on in vitro maturation of bovine oocytes is exerted through the cyclic adenosine $3^{\prime}, 5^{\prime}$-monophosphate signaling pathway. Biol Reprod 57: 1484-9.

Kim JY, Kinoshita M, Ohnishi M, Fukui Y (2001) Lipid and fatty acid analysis of fresh and frozen-thawed immature and in vitro matured bovine oocytes. Reproduction 122: 131-8.

Lapa M, Marques C, Alves S, Vasques M, Baptista M, Carvalhais I (2011) Effect of trans-10 cis-12 conjugated linoleic acid on bovine oocyte competence and fatty acid composition: effects of t10, c12 CLA on bovine oocytes. Reprod Domest Anim 46: 904-10.

Li HJ, Liu DJ, Cang M, Wang LM, Jin MZ, Ma YZ (2009) Early apoptosis is associated with improved developmental potential in bovine oocytes. Anim Reprod Sci 114: 89-98.

Liu Q, Zhou YF, Duan RJ, Wei HK, Jiang SW, Peng J (2015) Effects of dietary n-6:n-3 fatty acid ratio and vitamin $E$ on semen quality, fatty acid composition and antioxidant status in boars. Anim Reprod Sci 162: 11-9.

Lourenço B, Sousa AP, Almeida-Santos T, Ramalho-Santos J (2014) Relation of cumulus cell status with single oocyte maturity, fertilization capability and patient age. J Reprod Infertil 15: 15-21.

Marei WF, Ghafari F, Fouladi-Nashta AA (2012) Role of hyaluronic acid in maturation and further early embryo development of bovine oocytes. Theriogenology 78: 670-7.

Marei WF, Wathes DC, Fouladi-Nashta AA (2010) Impact of linoleic acid on bovine oocyte maturation and embryo development. Reproduction 139: 979-88.

Marquez CC, Baptista MC, Vasques MI, Horta AEM, Pereira RM (2007) Effect of polyunsaturated fatty acids (PUFA) on bovine oocyte in vitro maturation and subsequent embryo development and freezability. Reprod Domest Anim 109: 116.

Meng H, Shen Y, Shen J, Zhou F, Shen S, Das UN (2013) Effect of n-3 and n-6 unsaturated fatty acids on prostate cancer (PC-3) and prostate epithelial (RWPE-1) cells in vitro. Lipids Health Dis 12: 1 .

Møller P (2006) The alkaline comet assay: towards validation in biomonitoring of DNA damaging exposures. Basic Clin Pharmacol Toxicol 98: 336-45.

Nikoloff N, Ponzinibbio MV, Padula G, De Luca JC, Golijow C, Seoane A (2016) Folic acid enhances the apoptotic and genotoxic activity of carboplatin in HeLa cell line. Toxicol In Vitro 36: 142-7.

Olive PL (1999) DNA damage and repair in individual cells: applications of the comet assay in radiobiology. Int J Radiat Biol 75: 395-405.

Osman K, Hassan N, Ibrahim SF, Nang CF, Ismail Z (2013) Viability selection of bovine oocyte using annexin- $\mathrm{V}$ assay. J Agr Sci 5: 141-5.

Pitarque M, Vaglenov A, Nosko M, Hirvonen A, Norppa H, Creus A, Marcos R (1999) Evaluation of DNA damage by the comet assay in shoe workers exposed to toluene and other organic solvents. Mutat Res 441: 115-27.

Pläsier B, Lloyd DR, Paul GC, Thomas CR, Al-Rubeai M (1999) Automatic image analysis for quantification of apoptosis in animal cell culture by annexin- $\mathrm{V}$ affinity assay. $\mathrm{J}$ Immunol Methods 229: 81-95.

Robb J, Norval M, Neill WA (1990) The use of tissue culture for the detection of mycotoxins. Lett Appl Microbiol 10: 161-5.

Ruiz de Arcaute C, Soloneski S, Larramendy M (2016) Toxic and genotoxic effects of the 2,4-dichlorophenoxyacetic acid (2,4D)-based herbicide on the neotropical fish Cnesterodon decemmaculatus. Ecotoxicol Environ Saf 128: 222-9.

Santos CR, Schulze A (2012) Lipid metabolism in cancer. FEBS J 279: 2610-23.

Sarabi MM, Doosti M, Einollahi N, Hesami SS, Dashti N (2014) Effect of eicosapentaenoic acid on the expression of ABCG1 gene in the human monocyte THP-1 cells. Acta Medica Iranica 52: 176

Simopoulos AP (1989) Executive summary. Dietary w3 and w6 fatty acids: biological effects and nutricional essentiality plenum, pp. 391-402.

Singh NP, McCoy MT, Tice RR, Schneider EL (1988) A simple technique for quantitation of low levels of DNA damage in individual cells. Exp Cell Res 175: 184-91. 
Sofie Tanghe AVS (2002) Minireview: functions of the cumulus oophorus during oocyte maturation, ovulation, and fertilization. Mol Reprod Dev 61: 414-24.

Sturmey R, Reis A, Leese H, McEvoy T (2009) Role of fatty acids in energy provision during oocyte maturation and early embryo development. Reprod Domest Anim 44: 50-8.

Suss U, Stranzinger G, Wuthrich K (1998) Chromosome configurations and time sequence of the first meiotic division in bovine oocyte maturated in vitro. Biol Reprod 38: 871-80.

Takeuchi H, Inove J, Yoshida M, Wakatake S, Ichimura Y, Ema T, Muramatsu K (1989) Dietary effects of n-3 eicosapentaenoic acid on essential fatty acid- deficiency symptoms of rats. Agric Biol Chem 53: 3225-32.

Tatemoto H, Sakurai N, Muto N (2000) Protection of porcine oocytes against apoptotic cell death caused by oxidative stress during in vitro maturation: role of cumulus cells. Biol Reprod 63: 805-10.

Trujillo EP, Broughton KS (1995) Ingestion of n-3 polyunsaturated fatty acids and ovulation in rats. J Reprod Fertil 105: 197-203.

van Engeland M, Nieland LJ, Ramaekers FC, Schutte B, Reutelingsperger CP (1998) Annexin V-affinity assay: a review on an apoptosis detection system based on phosphatidylserine exposure. Cytometry 31: 1-9.
Veshkini A, Asadi H, Khadem AA, Mohammadi-Sangcheshmeh A, Khazabi S, Aminafshar M, Deldar H, Soleimani M, Ulas Cinar M (2015) Effect of linolenic acid during in vitro maturation of ovine oocytes: embryonic developmental potential and mRNA abundances of genes involved in apoptosis. J Assist Reprod Genet 32: 653-9.

Wathes DC, Abayasekara DRE, Aitken RJ (2007) Polyunsaturated fatty acids in male and female reproduction. Biol Reprod 77: 190-201.

Wrenzycki C, Stinshoff H (2013) Maturation environment and impact on subsequent developmental competence of bovine oocytes. Reprod Dom Anim 48: 38-43.

Wu J, Tu D, Yuan L-Y, Yuan H, Wen L-X (2013) T-2 toxin exposure induces apoptosis in rat ovarian granulosa cells through oxidative stress. Environ Toxicol Pharmacol 36: 493-500.

Yerram NR, Moore SA, Spector AA (1989) Eicosapentaenoic acid metabolism in brain microvessel endothelium: effect on prostaglandin formation. J Lipid Res 30: 1747-57.

Zajdel A, Wilczok A, Chodurek E, Gruchlik A, Dzierzewicz Z (2013) Polyunsaturated fatty acids inhibit melanoma cell growth in vitro. Acta Pol Pharm 70: 365-9.

Received 27 September 2016; accepted 13 February 2017. Final version published online 13 March 2017. 